\title{
Detection of Heavy Metal Contents in Sesame Oil Samples Grown in Korea Using Microwave-Assisted Acid Digestion
}

\author{
Min-Kyoung Park, Ji-Hyock Yoo, Je-Bong Lee, Geon-Jae Im, Doo-Ho Kim, and Won-II Kim* \\ Department of Agro-Food Safety, National Academy of Agricultural Science, \\ Rural Development Administration, Suwon 441-707, Korea
}

(Received July 20, 2012/Revised September 18, 2012/Accepted February 25, 2013)

\begin{abstract}
This study aimed to determine heavy metal contents in sesame oil samples produced in Korea through microwave-assisted acid digestion without using an emulsifier. Three heavy metal, cadmium $(\mathrm{Cd}), \mathrm{lead}(\mathrm{Pb})$ and arsenic (As) in twelve sesame oil samples were determined by ICP-MS. The validation of analysis method was checked by standard addition method $(10$ and $100 \mu \mathrm{g} / \mathrm{kg})$. As a result, linearity $\left(\mathrm{R}^{2}\right)$ was above 0.999 and RSDs were lower than $4 \%$. The recovery of $\mathrm{Cd}, \mathrm{Pb}$ and $\mathrm{As}$ ranged between $98.5-101.6 \%, 100.3-101.3 \%$, and 102.1-111.2\%, respectively. The detected ranges in sesame oil samples were as follows; N.D. to $0.109 \mu \mathrm{g} / \mathrm{g}$ for Cd, 0.014 to $0.200 \mu \mathrm{g} /$ $\mathrm{g}$ for $\mathrm{Pb}$ and 0.014 to $0.125 \mu \mathrm{g} / \mathrm{g}$ for As, respectively. Therefore, sesame seeds and products grown in heavy metalpolluted regions which are used as food should be given priority attention and consideration.
\end{abstract}

Key words: heavy metal, microwave-assisted acid digestion, sesame oil

\section{Introduction}

Vegetable oils are widely used in cooking, food processing, cosmetics, pharmaceuticals, and chemical industries ${ }^{1)}$. Among many vegetable oils, sesame oil is described to be of high nutritive and biological values as well as excellent quality taste. These qualities make sesame oil an irreplaceable and a regular condiment on Korean dining table ${ }^{2,3)}$. About 60,000 tons of sesame seeds were used in sesame oil production in Korea whose total domestic sesame oil consumption is 90,000 tons ${ }^{4)}$.

An important deciding factor in the assessment of quality on edible oils is the heavy metals composition. It is known that heavy metals affect the oils rate of oxidation, nutritional value, preservation properties, and storability. As such, the determination of heavy metal in vegetable oils is very important $t^{5}$.

Korea has set the legal limits for lead $(\mathrm{Pb})$ and arsenic (As) at $0.1 \mu \mathrm{g} / \mathrm{g}$ in edible oil, and Codex Alimentarius Commission (Codex) has the statutory limit in vegetable oils as well $^{6}$. The European Community also fixed the legal limits for $\mathrm{Pb}$ concentration in vegetable oils at $100 \mu \mathrm{g} / \mathrm{kg}^{7}$. However, there is no international legal limit on cadmium $(\mathrm{Cd})$ in vegetable oils or edible oils. Some researches on vegetable oil samples showed that there is no accumulation of heavy

\footnotetext{
*Correspondence to: Won-Il Kim, Department of Agro-Food Safety, National Academy of Agricultural Science, Rural Development Administration, Suwon 441-707, Korea
}

Tel: 82-031-290-0527, E-mail: wikim721@korea.kr metals, especially cadmium, in oil ${ }^{8)}$, while other researchers suggested opposite results ${ }^{9}$. There have been numerous reports on levels of heavy metals in various foods. However, there are limited reports in oil products ${ }^{8-10)}$.

These are due to some difficulty in determining the heavy metals in organic liquids, such as edible oils, which may have relatively high matrix effect for analyzing quantitatively low concentration level of heavy metals ${ }^{11,12}$. Various articles have been published on the determination of heavy metals in edible oils at parts-per-billion (ppb) levels using different spectroscopic techniques ${ }^{13,14)}$ or emulsifiers ${ }^{5,15)}$. In most cases, these methods are long and tedious with the consequent risk of sample contamination without any loss of analyte.

This study used an alternative procedure of simple dilution of oil with inorganic solvent, such as nitric acid, to determine the heavy metals in sesame oil samples. The quantitative analysis of $\mathrm{As}, \mathrm{Cd}$ and $\mathrm{Pb}$ in twelve newly breaded varieties of sesame oil using a microwave-assisted acid digestion method without an emulsifier was investigated.

\section{Materials and Methods}

\section{Reagents}

Analytical grade reagents of nitric acid (Dongwoo FineChem, Kyounggi, Korea) and hydrogen peroxide (SigmaAldrich, St. Louis, MO, USA) were used in the acid digestions. Each standard solution of $\mathrm{As}, \mathrm{Cd}$ and $\mathrm{Pb}$ was prepared by diluting with $2 \%(\mathrm{v} / \mathrm{v})$ nitric acid. To avoid contamination from various ions, all sorts of laboratory glasswares and plastic 
wares used were immersed in approximately $20 \%$ nitric acid and rinsed with ultrapure water prepared from a Milli-Q SP Reagent Water System (18 M $\Omega$, Millipore, Bedford, MA, USA).

\section{Sample Preparation}

Five samples of different varieties of sesame seeds were obtained from Rural Development Administration (Suwon, Korea), and another seven samples of those were collected from the sesame producing districts in Korea. These samples of sesame seeds were put in an electric roaster and roasted for 25 minutes at $135^{\circ} \mathrm{C}$ temperature. The samples of sesame oil were produced by mechanical pressing unit with a $600 \mathrm{kgf} / \mathrm{cm}$ from the roasted sesame seeds ${ }^{2,16}$.

\section{Digestion of samples}

A modified version of digestion method by Tinggi $[1998]^{17)}$ was used to determine the content of heavy metals in twelve samples of sesame oil. Portions of around $0.2 \mathrm{~g}$ of each sesame oil sample was added with $7 \mathrm{ml}$ mixture of acid and oxidant, nitric acid (65\%) and hydrogen peroxide $(30 \%)$ at $9: 1$ ratio in Teflon vessels, and then placed in a microwave oven (CEM Mars, CEM Corp., Matthews, NC, USA) for digestion. The digestion was carried out at four stages. Instrumental parameters for microwave digestion are shown in Table 1.

The digestion flasks were cooled to room temperature. The extracts were then evaporated to a semidried mass to remove excess acid and diluted with $50 \mu \mathrm{g} / \mathrm{L}$ indium (In) in $2 \%$ nitric acid to $10 \mathrm{ml}$ volumetric flasks. To assure the accuracy of the data, a regent blank (without sample) was performed in triplicate through the same procedures. Blanks and standard solutions were prepared in a similar acid matrix. All experiments were conducted at room temperature.

Table 1. Experimental scheme for the digestion of sesame oil using microwave oven

\begin{tabular}{cccc}
\hline Step & Temp $\left({ }^{\circ} \mathrm{C}\right)$ & Time $(\min )$. & Max. power $(\mathrm{W})$ \\
\hline 1 & $0-120$ & 5 & \\
2 & 120 & 5 & 1,000 \\
3 & $120-200$ & 10 & \\
4 & 200 & 30 & \\
\hline
\end{tabular}

Table 2. Optimal ICP-MS conditions using analytical method of sesame oil

\begin{tabular}{lc}
\hline \multicolumn{1}{c}{ Descriptions } & Conditions \\
\hline RF power/W & 1300 \\
Nebulizer & Concentric type \\
Plasma gas flow rate/ $\mathrm{L} \mathrm{min}$ & 10.00 \\
Auxiliary gas flow rate/ $\mathrm{L} \mathrm{min}^{-1}$ & 0.50 \\
Nebulizer gas flow rate/ $\mathrm{L} \mathrm{min}$ & 0.95 \\
\hline
\end{tabular}

\section{Analytical conditions of the ICP-MS}

The heavy metals in sesame oil samples were quantitatively measured by an Agilent 7500a ICP-MS (Agilent Technologies, Tokyo, Japan). The ICP-MS measurement condition was optimized for the determination of In. An internal standard of $\mathrm{m} / \mathrm{z} 115,20 \mu \mathrm{g} / \mathrm{L}$ was used in the quantitative analysis of this study. The optimal analysis conditions for ICP-MS are shown in Table 2.

\section{Method validation}

Little suitable Standard Reference Material (SRM) was commercially available for determining the heavy metal contents in edible oil or fat. In other studies conducted determination of heavy metals contents in oily food, the SRM have been replaced by the typically agricultural SRM or others as in water dropwort powder ${ }^{18,19)}$. In this study, the accuracy of this method was validated by analyzing SRM of spinach leaves $1577 \mathrm{c}$ (NIST, USA), which have a certified value of $\mathrm{Cd}, \mathrm{Pb}$ and $\mathrm{As}$.

Some reported that the spiked concentration of heavy metals in edible oil were at very low level which is below $10 \mu \mathrm{g} / \mathrm{kg}$ and have resulted to noise and instrumental interference effects ${ }^{20}$. Also, in this study, the efficiency of the microwave-assisted digestion method was checked by the spiked levels of heavy metals in sesame oils samples at 10 and $100 \mu \mathrm{g} / \mathrm{kg}$. The calibration was performed by using standard solutions in $2 \%$ nitric acid and the calibration curve levels of $\mathrm{Pb}, \mathrm{Cd}$ and As were $0,1,5,10,25,50,100 \mu \mathrm{g} / \mathrm{kg}$.

\section{Results and Discussion}

\section{Validation and analysis method}

This study used the microwave-assisted acid digestion method without emulsifier to analyze more easily and quickly the heavy metals contents in sesame oils. The data revealed an excellent coefficient of correlation range; linearity $\left(\mathrm{R}^{2}\right)$ of $\mathrm{Cd}, \mathrm{Pb}$ and As were all above 0.999 and Relative Standard Deviations (RSDs) were lower than 4\% (Table 3). The method detection limit (MDL) and method quantification limit (MQL) was calculated using the sigma method ${ }^{21)}$; the MDLs

Table 3. Validation method of $\mathrm{Cd}, \mathrm{Pb}$ and $\mathrm{As}$ in sesame oil using ICP-MS

\begin{tabular}{cccc}
\hline & $\mathrm{Cd}$ & $\mathrm{Pb}$ & $\mathrm{As}$ \\
\hline MDL $(\mu \mathrm{g} / \mathrm{L})$ & 0.59 & 0.47 & 0.55 \\
MQL $(\mu \mathrm{g} / \mathrm{L})$ & 1.19 & 0.94 & 1.11 \\
Linear & \multicolumn{4}{c}{$0.18 \mathrm{Y}=5.31 \mathrm{X}+0.58 \mathrm{Y}=0.87 \mathrm{X}-0.02$} \\
equation & $\mathrm{Y}=0.98 \mathrm{X}-0.18$ & 0.9998 \\
$\mathrm{R}^{2}$ & 0.9998 & 0.9999 & 3.42 \\
Precision $(\%)$ & 2.24 & 2.87 & 106.7 \\
Recovery $(\%)$ & 100.1 & 100.8 & \\
\hline
\end{tabular}


Table 4. Results of recovery test using standard addition method in sesame oil

\begin{tabular}{ccccc}
\hline \multirow{2}{*}{$\begin{array}{c}\text { Heavy } \\
\text { metal }\end{array}$} & \multicolumn{4}{c}{ Spiked conc. } \\
\cline { 2 - 5 } & $\begin{array}{c}\text { Detected } \\
\text { conc. }(\mu \mathrm{g} / \mathrm{kg})\end{array}$ & $\begin{array}{c}\text { Recovery } \\
(\%)\end{array}$ & $\begin{array}{c}\text { Detected } \\
\text { conc. }(\mu \mathrm{g} / \mathrm{kg})\end{array}$ & $\begin{array}{c}\text { Recovery } \\
(\%)\end{array}$ \\
\hline $\mathrm{Cd}$ & $10.2 \pm 2.2$ & 101.6 & $98.5 \pm 1.5$ & 98.5 \\
$\mathrm{~Pb}$ & $10.0 \pm 2.2$ & 100.3 & $101.3 \pm 4.3$ & 101.3 \\
$\mathrm{As}$ & $11.1 \pm 2.5$ & 111.2 & $102.1 \pm 2.5$ & 102.1 \\
\hline
\end{tabular}

Table 5. The efficiency of heavy metal concentrations in standard reference materials (NIST SRM 1577c spinach leaves)

\begin{tabular}{cccc}
\hline Heavy metal & $\begin{array}{c}\text { Certified value } \\
(\mu \mathrm{g} / \mathrm{g})\end{array}$ & $\begin{array}{c}\text { Detected value } \\
(\mu \mathrm{g} / \mathrm{g})\end{array}$ & Efficiency (\%) \\
\hline $\mathrm{Cd}$ & 2.890 & $2.529 \pm 0.090$ & 87.5 \\
$\mathrm{~Pb}$ & 0.200 & $0.226 \pm 0.006$ & 112.8 \\
$\mathrm{As}$ & 0.068 & $0.059 \pm 0.006$ & 86.9 \\
\hline
\end{tabular}

were $0.59,0.47$ and $0.55 \mu \mathrm{g} / \mathrm{L}$, and MQLs were $1.19,0.94$ and $1.11 \mu \mathrm{g} / \mathrm{L}$ for $\mathrm{Cd}, \mathrm{Pb}$ and $\mathrm{As}$, respectively.

In order to check the accuracy of the proposed methodology, the spike and recovery experiments were carried out for each element at 10 and $100 \mu \mathrm{g} / \mathrm{kg}$. The results are shown in Table 4. The accuracy and precision of the results, estimated in a percent average of the standard addition recoveries, was higher than $98 \%$ at both spiked levels; Recoveries were found to be $98.5-101.6 \%, 100.3-101.3 \%$ and $102.1-111.2 \%$ for $\mathrm{Cd}, \mathrm{Pb}$ and $\mathrm{As}$, respectively.

The accuracy and precision of this method was further validated by analyzing the SRM1577c, spinach leaves which have a certified value of $\mathrm{Cd}, \mathrm{Pb}$ and As. Table 5 showed good results with certified values achieved.

There have been many attempts of using emulsifiers to the analysis of heavy metals in edible oils and fats ${ }^{5,15,22}$. Emulsifiers such as Triton X-100, Tween 20 and Span 20 were used in the analysis of edible oils and fats. According to the results, the optimum amount of oil in the emulsion was in the range $c a .2-35 \%$ in most of the surfactants studies and the digestive method using emulsifiers may reduce the organic content of the sample by at least $95 \%$. However, the problem when using emulsions may reside in maintaining the stability of samples for an acceptable period of time. Therefore, in analyzing method using emulsion was to obtain optimum formation and stabilization conditions of the emulsion, type and quantity of the emulsifier, stirring time and mode, etc. Study for quantitative determination of metals in olive oil using direct emulsion nebulization suggested that the most stable emulsion be obtained with Triton X-100 and the emulsion may be stable with $1.5 \mathrm{ml}$ Triton $\mathrm{X}-100$ for at least 4 hours with up to $4 \mathrm{~g}$ of oil ${ }^{15)}$.

In this study, microwave digestion employed nitric acid as digesting acid and hydrogen peroxide as alternative to break down the bonds in lipid molecules. The digestive method in this study takes less than 1 hour, saving more time to reach complete digestion. Chen et al. reported that sulfuric acid per se as digesting acid was unable to completed digest lipid, but mixtures of sulfuric acid and nitric acid presented comparable digestive efficiencies ${ }^{13)}$. On the other hand, the digestive was vigorous during the heating processes, when the digestion was carried out in the mixture of sulfuric acid and nitric acid. Therefore, these results suggested that the microwave-assisted digestion with nitric acid may offer a safe and simple alternative for the analysis of a large number of oil samples at a given a minimum time.

\section{Heavy metal contents in sesame oil samples}

Twelve samples of sesame oil were analyzed for their heavy metals contents by ICP-MS with microwave-assisted acid digestion method as described above. The heavy metal contents in twelve samples of sesame oil grown in Korea are shown in Table 6 . The detected ranges in sesame oil samples were as follows: N.D. to $0.109 \mu \mathrm{g} / \mathrm{g}$ for Cd, 0.014 to $0.200 \mu \mathrm{g}$ / $\mathrm{g}$ for $\mathrm{Pb}$ and 0.014 to $0.125 \mu \mathrm{g} / \mathrm{g}$ for As, respectively.

According to Korea's maximum permitted concentration (MPC) for heavy metals in edible oils, about $17 \%$ and $7 \%$ samples of sesame oils grown in Korea were above the legal limit for $\mathrm{Pb}$ and $\mathrm{As}$, respectively. However, an excess rate of legal limit for $\mathrm{Cd}$ could not be estimated in sesame oil samples grown in Korea, because no legislation for Cd limits in edible oils currently exists in Korea and in other countries as well. These results suggested to set up domestic legal limits of $\mathrm{Cd}$ to ensure the quality assurance of sesame oils.

Table 7 showed the contents of heavy metals in vegetable oil samples in other countries as cited in literatures ${ }^{1,13,19,20,23-25)}$. Vegetable oil samples, including sesame oils, grown in China were reported to range from 3.34 to $5.44 \mu \mathrm{g} / \mathrm{g}$ for Cd contents while oil samples from Turkey, Italy and Pakistan has much higher $\mathrm{Cd}$ contents compared to other countries. The detected values for $\mathrm{Cd}$ in sesame oil samples grown in Korea were much lower than the reported values in most other countries as shown in Table 6.

According to the results by Zhu et al.(2011), the $\mathrm{Pb}$ and As levels of vegetable oils in China ranged from 0.006 to $0.014 \mu \mathrm{g} / \mathrm{g}$ and 0.007 to $0.018 \mu \mathrm{g} / \mathrm{g}$, respectively ${ }^{19)}$, similarly

Table 6. The contents of heavy metals $(\mu \mathrm{g} / \mathrm{g})$ in sesame oil samples, $\mathrm{N}=12$

\begin{tabular}{cccc}
\hline Heavy metals & Mean & Range & Limit level in Korea \\
\hline $\mathrm{Cd}$ & 0.018 & $\mathrm{ND} \sim 0.109$ & - \\
$\mathrm{Pb}$ & 0.055 & $0.014 \sim 0.200$ & 0.1 (edible oils) \\
$\mathrm{As}$ & 0.038 & $0.014 \sim 0.125$ & 0.1 (edible oils) \\
\hline
\end{tabular}


Table 7. Reported contents of heavy metals $(\mu \mathrm{g} / \mathrm{g})$ in vegetable oil samples

\begin{tabular}{|c|c|c|c|c|c|}
\hline Country & Oil samples & $\mathrm{Cd}$ & $\mathrm{Pb}$ & As & Reference \\
\hline \multirow{3}{*}{ China } & Sesame oil & $5.27 \sim 5.44$ & $0.014 \sim 0.018$ & $0.015 \sim 0.018$ & \multirow{3}{*}{19} \\
\hline & Olive oil & $2.39 \sim 2.64$ & $0.009 \sim 0.013$ & $0.008 \sim 0.012$ & \\
\hline & Sunflower oil & $3.34 \sim 3.51$ & $0.006 \sim 0.010$ & $0.007 \sim 0.011$ & \\
\hline UK & Sesame oil & - & $\mathrm{ND} \sim 0.051$ & - & 23 \\
\hline \multirow[t]{2}{*}{ Italy } & Sunflower oil & $0.51 \sim 4.15^{\mathrm{a}}$ & $0.005 \sim 0.016$ & - & 1 \\
\hline & Olive oil & $0.15^{\mathrm{a}}$ & 0.03 & - & \multirow{2}{*}{25} \\
\hline \multirow{3}{*}{ Turkey } & Sunflower oil & 0.004 & 0.01 & - & \\
\hline & Olive oil & 0.002 & 0.010 & - & \multirow{2}{*}{20} \\
\hline & Sunflower oil & $0.7 \sim 1.9^{\mathrm{a}}$ & $0.011 \sim 0.023$ & - & \\
\hline Pakistan & Sunflower oil & $1.70 \sim 6.18$ & $0.79 \sim 4.29$ & - & 24 \\
\hline \multirow{4}{*}{ Taiwan } & Sesame oil & - & - & $0.006,0.011$ & \multirow{4}{*}{13} \\
\hline & Olive oil & - & - & $0.006,0.012$ & \\
\hline & Sunflower oil & - & - & $0.005,0.006$ & \\
\hline & Vegetable oil & - & - & 0.011 & \\
\hline
\end{tabular}

${ }^{\mathrm{a}} \mu \mathrm{g} / \mathrm{kg}$

with those in other countries, except in Pakistan ${ }^{1,13,19,20,23-25)}$. $\mathrm{The} \mathrm{Pb}$ and As contents in sesame oil samples showed also similar range with other vegetable oils in China, although limited data about the presence of the heavy metals in sesame oil samples ${ }^{13,13,19,23)}$.

In terms of the mean value detected for $\mathrm{Pb}$ and $\mathrm{As}$, sesame oil samples were found to have a similar values with those in other literatures. However, the maximum values $(0.200 \mu \mathrm{g} / \mathrm{g}$ and $0.125 \mu \mathrm{g} / \mathrm{g}$ for $\mathrm{Pb}$ and $\mathrm{As}$, respectively) detected in sesame oils grown in Korea were much higher compared to the top values detected in sesame oils in other literatures.

The sesame oil, among other sesame products, has been the main commercial product from sesame seeds in domestic markets ${ }^{4}$ and it's consumption may be the contributing factor of dietary exposure route of heavy metals in Korean. The heavy metals have been known as hazardous substances when taken and accumulated in the human body may harm human organs since they do not decomposed. It is proven that $\mathrm{Cd}$ highly accumulated in human kidney and liver and causes "leukemia"19). Therefore, sesame seeds and products grown in heavy metal-polluted regions being used as food should be given priority attention and consideration.

For future study, the transition rate of $\mathrm{Cd}$ ion through the extraction process from sesame seed to sesame oil should be further investigated. Likewise, there should be an indepth study, in terms of the relationship of each heavy metal-contaminated level in seeds.

\section{요 약}

본 연구에서는 유화제를 사용하지 않고 초단파 산분해 법을 이용해 우리나라에서생산된 참기름의 중금속을 측정 하고자 하였다. ICP-MS를 통해 12 개의 참기름 시료에 오
염된 카드뮴, 납, 비소의 3종 중금속을 분석하였다. 분석법 의 검증 결과 카드뮴, 납, 비소 모두 직선성 $\left(\left(\mathrm{r}^{2}\right)\right.$ 이 0.99 이 상이며 RSD는 $4 \%$ 이하였다. 또한, 분석법의 정확성 및 효 율성 측정을 위해 중금속 $10 \mu \mathrm{g} / \mathrm{g}$ 과 $100 \mu \mathrm{g} / \mathrm{g}$ 을 첨가한 시료를 분석한 결과, 회수율이 카드뮴 98.5-101.6\%, 납 100.3$101.3 \%$, 비소 102.1-111.2\%로 우수하게 나타났다. 본 분석 법을 이용하여 분석한 참기름 시료의 중금속 함량은 카드 뮴 불검출 $0.109 \mu \mathrm{g} / \mathrm{g}$, 납 $0.014 \sim 0.200 \mu \mathrm{g} / \mathrm{g}$, 비소 $0.014 ~$ $0.125 \mu \mathrm{g} / \mathrm{g}$ 이었다. 따라서, 중금속 오염지역에서 생산된 참 깨 및 이를 이용한 가공품의 경우 섭취에 주의할 필요가 있다.

\section{Acknowledgement}

This work was supported by a grant from the Agenda Program (PJ00865004 and PJ00644603), Rural Development Administration, Republic of Korea.

\section{References}

1. Dugo, G., Pera, L.L., La Torre, GL. and Giuffrida, D.: Determination of $\mathrm{Cd}(\mathrm{II}), \mathrm{Cu}(\mathrm{II}), \mathrm{Pb}(\mathrm{II})$, and $\mathrm{Zn}(\mathrm{II})$ content in commercial vegetable oils using deriavative potentiometric stripping analysis. Food Chemistry, 87, 639-645 (2004).

2. Namiki, M.: The chemistry and physiological functions of sesame. Food Reviews International, 11, 281-329 (1995).

3. Yamashita, K., Iizuka, Y., Imai, T. and Namiki, M.: Sesame seed and its lignans produce marketed enhancement of vitamin E activity in rats fed a low $\alpha$-tocopherol diet. Lipids, 10, 1019-1028 (1995).

4. Kang, M.H., Ryu, S.N., Ban, J.K., Kang, C.H., Kim, D.H. and Lee, B.H.: Physicochemical properties of introduced and domestic sesame seeds. J Korean Soc Food Sci. Nutr., 29, 188- 
$192(2000)$.

5. Murillo, M., Benzo, Z., Marcano, E., Gomez, C., Garaboto, A. and Marin, C.: Determination of cooper, iron and nickel in edible oils using emulsified solutions by ICP-AES. J. of Analytical Atomic Spectrometry, 14, 815-820 (1999).

6. Codex Alimentarius Commission. Codex general standard for contaminants and toxins in food and feed. CODEX STAN 193-1995.

7. EC Commision. Regulation CE466/2001. Maximum levels for certain contaminants in foodstuffs. EC Commision, Brussels, Belgium (2001).

8. Cruz, A.R., Vique, C.C., Tovar, M.L.L. and Martinez, M.C.L.: Lead and cadmium content in sunflower oil. Grassas $y$ Aceites, 52, 229-234 (2001).

9. Bednarova, J.: Hromadei olova vybranymi populacemi roslin. Acta Univ. palack. olomuc fac. rerum natur Biol., 93(28), 2125 (1988).

10. Tahvonen, R.: Contents of lead and cadmium in food and diets. Food Reviews International, 12, 1-70 (1996).

11. De Leorardis, A., Macciola, V. and De Felice, M.: Copper and iron determination inedible vegetable oils by graphite furnace atomic absorption spectrometry after extraction with diluted nitric acid. International J. of Food Science and Technology, 35(4), 371-375 (2000).

12. Bati, B. and Cesur, H.: Determination of copper in edible oils by atomic absorption spectrometry after lead piperazinedithiocarbamate solid-phase extraction and potassium cyanide backextraction. Analytical Science, 18, 1273-1274 (2002).

13. Chen, S.S., Lee, I.Y., Cheng, C.C. and Chou, S.S.: Determination of arsenic in edible fats and oils by focused microwave digestion and atomic fluorescence spectrometer. Journal of Food and drug Analysis, 9(2), 121-125 (2001).

14. Mendil, D., Uluozlu, O.D., Tuzen, M. and Soylak, M.: Investigation of the levels of some element in edible oil samples produced in Turkey by atomic absorption spectrometry. Journal of Hazardous Materials, 165, 724-728 (2009).
15. Castillo, J.R., Jimenez, M.S. and Ebdon, L.: Semiquantitative simultaneous determination of metals in olive oil using direct emulsion nebulization. J. Anal. At. Spectrom., 14, 1515-1518 (1999).

16. Lee, S.W., Jeung, M.K., Park, M.H., Lee, S.Y. and Lee, J.H.: Effect of roasting conditions of sesame on the oxidative stability of pressed oil during thermal oxidation. Food Chemistry 118, 681-685 (2010).

17. Tinggi, U.: Cadmium levels in peanut products. Food Addictive and Contaminant, 15, 789-792 (1998).

18. KFDA. Monitoring of heavy metals in vegetables. Seoul, Korea (2009).

19. Zhu, F., Fan, W., Wanng, X., Qu, L. and Yao, S.: Health risk assessment of eight heavy metals in nine varieties of edible vegetables oils consumed in China. Food and Chemical Toxicology, 49, 3081-3085 (2011).

20. Pehlivan, E., Arslan, G., Gode, F., Altun, T. and Mosa Özcan, M.: Determination of some inorganic metals in edible vegetable oils by inductively coupled plasma atomic emission spectroscopy (ICP-AES). Grasas Y Aceites, 59(3), 239-244(2008).

21. EFSA: Scientific Opinion on arsenic in food. EFSA Journal, 7(10), 1351 (2009).

22. Anthemidis, A.N., Arvanitidis, V. and Stratis, J.A.: On-line emulsion formation and multi-element analysis of edible oils. Analytica Chimica Acta, 537, 271-278 (2005).

23. MAFF. Metals in cold pressed oils, Index to MAFF UK Food Surveillance Information Sheets. London, UK (1997).

24. Ansari, R., Kazi, T.G., Jamali, M.K., Arain, M.B., Wagan, M.D., Jalbani, N., Afridi, H.I. and Shah, A.Q.: Variation in accumulation of heavy metals in different verities of sunflower seed oil with the aid of multivariate technique. Food Chemistry, 115, 318-323 (2009).

25. Mendil, D., Uluozlu, O.D., Tuzen, M. and Soylak, M.: Investigation of the levels of some element in edible oil samples produced in Turkey by atomic absorption spectrometry. Journal of Hazardous Materials, 165, 724-728 (2009). 